\title{
PENERAPAN NILAI MATEMATIK DALAM KALANGAN GURU MATEMATIK SEKOLAH MENENGAH KEBANGSAAN LUAR BANDAR
}

\author{
${ }^{1}$ Law Hui Nong, ${ }^{2}$ Mazlini Adnan \\ ${ }^{1,2}$ Fakulti Sains dan Matematik, Universiti Pendidikan Sultan Idris \\ 35900 Tanjong Malim, Perak
}

Received : 12 April 2017; Accepted : 16 Ogos 2017; Published : 15 December 2017

\begin{abstract}
Abstrak
Kajian ini bertujuan untuk meneroka penerapan nilai matematik dan kefahaman nilai matematik dalam kalangan guru matematik sekolah menengah kebangsaan luar bandar. Kajian ini melibatkan tiga orang guru daripada sebuah sekolah menengah kebangsaan di daerah Kapit, Sarawak. Data kualitatif diperoleh melalui pemerhatian pengajaran bilik darjah, temu bual secara individu, catatan lapangan dan rancangan pengajaran harian. Kesemua sesi temu bual dirakam menggunakan alat perakam audio. Dapatan kajian menunjukkan bahawa penerapan nilai matematik terlaksana dalam pengajaran secara tersirat, khususnya nilai objektisme. Guru-guru matematik mempercayai bahawa sesuatu yang boleh dinampak, seperti objek dapat membantu murid membina konsep matematik yang lebih kukuh. Dapatan ini juga memperlihatkan guru berperanan menerangkan konsep pada awal pengajaran, di samping contoh sebelum akhirnya menyuruh pelajar menyelesaikan masalah. Pengajaran matematik didapati lebih berpusatkan guru di mana guru akan mencuba memastikan pelajarnya mendengar segala yang diajar dan diarahkan oleh guru. Pengajaran sebegini dianggap oleh guru lebih berkesan dan mudah difahami pelajar. Dengan kecenderungan guru sebeginilah yang memungkinkan pelajar menjadi kurang berkeupayaan untuk berdikari dalam pembelajaran matematik mereka. Jadi, nilai matematik seperti rasionalisme yang mementingkan penghujahan murid dan nilai keterbukaan yang menggalakkan murid membuktikan sesuatu formula kurang dititik beratkan. Selain itu, dapatan ini memperlihatkan nilai matematik merupakan komponen nilai yang terlalu asing bagi guru yang terlibat dalam kajian ini. Ketiga - tiga sampel kajian ini berpendapat bahawa nilai matematik adalah sama dengan nilai- nilai murni, iaitu nilai pendidikan umum.
\end{abstract}

Kata kunci Nilai Matematik Dan Nilai Pendidikan Umum.

\begin{abstract}
This study aims to explore the application of mathematical values and the understanding of mathematical value among the rural mathematics teachers of the national secondary school. The study involved three teachers from a national secondary school in Kapit district, Sarawak. Qualitative data is obtained through classroom teaching observation, individual interviews, field notes and daily lesson plans. All interview sessions were recorded using the audio recorder. The findings show that the application of mathematical
\end{abstract}


values is implied in teaching implicitly, especially the value of objectivity. Mathematical teachers believe that something that can be impacted, such as objects can help pupils build stronger mathematical concepts. This finding also shows that the teacher plays a role in describing the concept at the beginning of the lesson, in addition to the example before finally enabling the student to solve the problem. Mathematical teaching is found to be more teacher-centered in which the teacher will try to ensure that his students listen to what is taught and directed by the teacher. Such teaching is considered by teachers to be more effective and understandable to the students. With such a tendency the teacher allows students to be less capable of self-reliance in their mathematical learning. Thus, the value of mathematics such as rationalism which concerns the student's argument and the value of openness that encourages the student to prove a formula is less stressful. In addition, this finding shows that mathematical value is a component of value that is too foreign to the teachers involved in this study. The three samples of this study argue that the value of mathematics is equal to pure values, namely the value of general education.

Keywords Values In Mathematics, General Values.

\section{PENGENALAN}

Matematik dikenali sebagai suatu mata pelajaran yang tidak menarik, kering, sukar dan membosankan (Mohd Uzi, 2010). Masalah ini berpunca daripada matematik dilihat sebagai mata pelajaran yang tidak bermakna dan tidak mempunyai perkaitan secara langsung dengan kehidupan seharian. Fakta-fakta yang dibincangkan dianggap asing dan seolah-olah berasingan dengan dunia ini. (Wan Zah et al., 2005). Selain itu, ramai pendidik matematik percaya bahawa nilai yang dibawa oleh guru matematik dalam pelbagai aspek dalam kerjaya akan memberi kesan yang mendalam kepada bagaimana mereka mengajar justeru bagaimana dan apa yang dipelajari oleh murid mereka (Mohd Uzi, 2010). Maka, semakin guru matematik memahami tentang kedudukan nilai pedagogi mereka, pemikiran mereka dan apa yang dipraktiskan semasa pengajaran matematik turut menjadi semakin fleksibel (Lin et al., 2006). Justeru, ramai juga penyelidik masa kini (Mohd Uzi, 2010; Wan Zah et al., 2005) berpendapat bahawa aspek nilai perlu diberi keutamaan dalam penyelidikan pendidikan dalam mengatasi masalah dalam pendidikan matematik. Wan Zah et al. (2005), berpendapat bahawa pendekatan pengajaran yang menekankan penerapan nilai matematik akan menjadikan pengajaran lebih berkesan, menarik, bermakna dan berguna kepada pelajar. Hal ini kerana nilai matematik akan membangkitkan rasa keindahan terhadap matematik, membangkitkan kefahaman tentang kepentingan matematik dalam kehidupan dan dapat membantu pelajar menguasai kekuatan matematik dengan lebih baik (Mohd Uzi, 2012).

\section{NILAI DALAM PENDIDIKAN MATEMATIK}

Umumnya, nilai dalam pendidikan matematik boleh dikategorikan kepada tiga jenis iaitu nilai pendidikan umum, nilai matematik dan nilai pendidikan matematik (Mohd Uzi \& Lim, 2009). Nilai pendidikan umum ialah kualiti yang ingin dilaksanakan penerapan 
oleh para guru, sekolah, masyarakat atau budaya kepada pelajar di bilik darjah bagi menyediakan pelajar sebagai individu dan ahli dalam masyarakat. Contohnya ialah nilai berkerjasama, nilai rajin dan nilai cekal. Nilai matematik pula ialah kualiti berkait dengan sifat pengetahuan matematik itu sendiri, iaitu tentang cara bagaimana disiplin matematik dibina oleh ahli matematik dalam berbagai budaya atau aspek epistemological matematik sebagai suatu disiplin (Mohd Uzi, 2010). Nilai pendidikan matematik ialah nilai yang terterap melalui amalan dan norma dalam pengajaran dan pembelajaran matematik sebagaimana yang dianjurkan oleh guru, buku matematik ataupun pihak sekolah. Tiga pasangan nilai matematik ialah: nilai rasionalisme dan nilai objektisme; nilai kawalan dan nilai kemajuan; dan nilai keterbukaan dan nilai misteri.

\section{NILAI MATEMATIK}

Nilai matematik ialah kualiti berkait dengan sifat-sifat pengetahuan matematik itu sendiri, yang dibina oleh ahli matematik dalam pelbagai budaya (Mohd Uzi, 2010). Nilai matematik berkait dengan aspek epistemologikal matematik sebagai suatu disiplin. Aspek epistemologikal ialah cabang falsafah yang meneliti sifat, asal usul, sumber, kaedah, kesahan, skop dan batasan pengetahuan manusia.

Tiga tahap perkembangan nilai matematik ialah tahap ideologi (matematik), tahap sentimen (individu) dan tahap masyarakat (sosiologi) (Mohd Uzi, 2010; Nik Azis, 2009). Nilai pada tahap ideologi membabitkan kepercayaan individu tentang pengetahuan matematik yang bergantung kepada falsafah dan simbol tertentu (Nik Azis, 2009). Contoh dua nilai dalam tahap ini ialah nilai rasionalisme dan objektisme.

\section{Rasionalisme - objektisme}

Nilai yang dominan yang bersabit dengan matematik adalah rasionalisme yang mambabitkan idea yang bergantung kepada logik, andaian (hypothetical) dan hujah (Seah \& Bishop, 2000). Rasionalisme memfokuskan kepada penghujahan deduktif sebagai cara memperoleh penjelasan dan kesimpulan (Seah \& Bishop, 2000). Nilai objektisme adalah berkait dengan idea seperti membina simbol dan pengkonkritan (concretizing). Nilai objektisme menggambarkan kekuatan matematik yang berurusan dengan idea yang abstrak secara berkesan dengan menjadikannya konkrit (seperti nombor, simbol dan rajah), iaitu mempertimbangkan idea sebagaimana ianya objek (Seah \& Bishop, 2000: Bishop, 1988).

Nilai pada tahap sentiment (individu) membabitkan sikap, emosi, pandangan, dan perasaan individu tentang pengetahuan matematik (Nik Azis, 2009). Contoh nilai dalam tahap ini ialah nilai kawalan dan nilai kemajuan.

\section{Kawalan - kemajuan}

Nilai kawalan adalah merujuk kepada perasaan keselamatan yang ditawarkan oleh matematik, bukan sahaja bagi menyelesaikan permasalahan melibatkan fenomena semula jadi, tetapi juga apabila matematik digunakan untuk menyelesaikan masalah dalam persekitaran sosial (Seah \& Bishop, 2000). Nilai kawalan melibatkan aspek- 
aspek seperti memiliki peraturan (rules), berkeupayaan menjangka, dan berkebolehan mengaplikasikan idea kepada situasi-situasi penyelesaian masalah dalam persekitarannya (Bishop et al., 2000). Nilai kemajuan adalah pelengkap kepada nilai kawalan, yang berkait dengan perubahan dan pembangunan dalam matematik. Nilai kemajuan dikenal pasti apabila pelajar berupaya membuat generalisasi terhadap sesuatu idea atau prosedur penyelesaian masalah matematik, untuk digunakan di dalam situasi masalah yang lain (Bishop et al.,2000).

Nilai pada tahap masyarakat (sosiologi) membabitkan tanggapan individu dalam aspek sosial bagi pengetahuan matematik atau konsepsi individu tentang saling hubungan antara pengetahuan matematik dengan masyarakat (Nik Azis, 2009). Contoh nilai ini ialah nilai keterbukaan dan nilai misteri. Nilai keterbukaan berkait dengan kepercayaan ahli matematik tentang keperluan mendapatkan pengesahan masyarakat umum (seperti melalui pembuktian dan demonstrasi) mengenai sesuatu idea yang mereka miliki. Kajian oleh Seah, Bishop, FitzSimons dan Clarkson (2001) terhadap guru sekolah rendah (iaitu Diane) menunjukkan, walaupun nilai keterbukaan tidak dinyatakan dalam rancangan pengajarannya, namun nilai tersebut dikesan.

\section{Nilai keterbukaan - misteri}

Nilai keterbukaan adalah tentang kefahaman bahawa kebenaran suatu pernyataan atau idea matematik adalah terbuka untuk diselidiki oleh sesiapa asalkan memiliki pengetahuan yang berkaitan (Bishop, 1988). Contohnya, Teorem Pithagoras adalah terbuka untuk dibuktikan kebenarannya oleh pelajar dalam aktiviti geometri. Nilai misteri adalah berkait dengan kesukaran memberi makna atau memahami simbolsimbol dan konsep-konsep matematik yang dipelajari. Oleh itu, asas bagi nilai misteri dalam pendidikan matematik adalah simbol-simbol dan konsep-konsep matematik itu sendiri.

\section{TUJUAN KAJIAN}

Kajian ini dijalankan dengan tujuan meneroka nilai matematik yang diterapkan dalam kalangan guru matematik sekolah menengah luar bandar dan mendalami kefahaman nilai matematik guru matematik sekolah menengah luar bandar.

\section{METODOLOGI}

Kajian yang dijalankan berbentuk kualitatif. Ia bertujuan untuk mendalami nilai matematik guru matematik sekolah menengah di luar bandar. Kajian tinjauan ini dapat mengumpul jawapan yang terus daripada subjek kajian. Oleh itu, ia sesuai digunakan untuk pengkaji membuat ramalan tentang sesuatu isu kefahaman nilai matematik di kalangan guru (Chua 2011).

Bagi mendalami nilai pendidikan matematik, kajian perlu dilaksanakan dalam situasi pengajaran bilik darjah sebenar, dengan mengambil kira konteks dan proses pengajaran bilik darjah. Oleh itu, pendekatan yang paling sesuai ialah penyelidikan kualitatif. Data kualitatif merupakan sumber yang berasaskan fakta yang kaya dengan 
deskriptif dan penjelasan tentang proses dan konteks tempatan (John \& Christensen, 2000).

Kajian ini dijalankan dengan menggunakan pendekatan interpretif. Satu temubual dijalan dan dirakamkan antara penyelidik dengan sampel kajian untuk mendapatkan gambaran tentang kefahaman nilai matematik yang ada dalam diri sampel kajian. Temu bual juga dibuat bagi mendapat penjelasan lanjut tentang perkaraperkara yang masih kurang jelas atau mengelirukan, serta mendapatkan pengesahan tentang beberapa kategori nilai terterap secara disedari atau tidak disedari oleh sampel kajian. Temu bual lepas kajian bagi setiap peserta ditamatkan hanya apabila pengkaji berpuas hati dengan maklumat yang diberikan oleh peserta, disamping berlaku ketepuan data. Selain itu, pemerhatian proses pengajaran dalam bilik darjah juga dirakam dengan menggunakan alat perakam video. Seterusnya, catatan lapangan juga dilakukan melalui pemerhatian penyelidik sepanjang proses pengajaran. Akhir sekali, rancangan pengajaran harian sampel kajian juga diteliti dari segi catatan nilai dan refleksi pengajaran.

Kajian ini melibatkan tiga orang guru matematik sekolah menengah luar bandar iaitu di bahagian Kapit, Sarawak. Tiga orang sampel kajian iaitu Cikgu A, Cikgu B dan Cikgu C (bukan nama sebenar). Teknik persampelan yang digunakan ialah teknik persampelan bertujuan di mana kajian ini bertujuan untuk meneroka nilai matematik yang ada atau menjadi pegangan seseorang individu. Dalam kajian ini, individu yang terlibat ialah guru matematik.

\section{DAPATAN KAJIAN DAN PERBINCANGAN}

Berikut dibincangkan dapatan kajian mengenai penerapan nilai dan kefahaman nilai yang ada di dalam Cikgu A, Cikgu B dan Cikgu C.

\section{Penerapan Nilai}

Bahagian ini menerangkan penerapan nilai bagi tiga sampel kajian. Secara umumnya, kesemua nilai matematik terterap dalam pengajaran kelas secara tersirat.

\section{a. Pengajaran Cikgu $A$}

Tiga nilai matematik yang telah dikenal pasti terterap dalam pengajaran Matematik oleh Cikgu A ialah rasionalisme, objektisme, kawalan dan kemajuan. Semua nilai ini terterap secara tersurat.

\section{i. Objektisme}

Satu lagi nilai yang dikesan daripada pengajaran Cikgu A ialah nilai objektisme. Cikgu A menggunakan buku yang ada pada mejanya berserta dengan marker pen sebagai bahan bantu mengajar untuk membina idea yang abstrak secara berkesan dengan menjadikannya pengetahuan yang konkrit. Ini boleh ditunjukkan oleh Cikgu A semasa mengulangi ciri-ciri garis pada satah: 
Sambil mengangkat sebuah buku dari meja, Cikgu A berusaha menggambarkan satu satah mengufuk dengan menyokong buku itu dengan tangan kanan. "Katakan ini satah, cikgu letak marker pen." Cikgu A memegang satu pen marker dari meja dan meletakkan di atas permukaan buku itu. "Marker pen ini ialah garis pada satah. Kalau cikgu letak pada tepi?" Cikgu A mengalihkan pen marker itu ke sebelah kiri sisi buku. "Ya. Garis pada satah".

Semasa menjelaskan perbezaan antara garis pada satah dan garis bersilang pada satah, Cikgu A marker pen sekali lagi menggunakan buku dan marker pen di atas meja sebagai bahan yang memberikan gambaran konkrit kepada anak murid:

Cikgu A mengambil buku dari meja dan menyokong buku itu dengan tangan kanan. "Okey. Kalau garis pada satah, ia selari dengan satah." Sambil bercakap Cikgu A memegang marker pen dengan tangan kiri dan meletakkannya di atas buku itu.

Cikgu A sambung untuk menerangkan garis bersilang dan titik bersilang pada satah:

"Kalau garis yang menegak, (Cikgu A menegakkan marker pen) condong, (Cikgu A condongkan dengan kepala marker pen menyentuh kulit buku), ia adalah garis bersilang".

Cikgu A menyokong buku dengan tangan kanan. Secara perlahan, Cikgu A memegang marker pen dan menghala kepala pen marker itu kepada kulit buku. "Mana titik yang bersilang? Yang ni, tanda merah ni." Cikgu A menjauhkan marker pen dan mendekatkan kepala marker pen kepada kulit buku. "Titik ini ialah titik yang bersilang."

\section{ii. Kawalan}

Cikgu A cuba menerapkan nilai kawalan dalam pengajaran dalam bilik darjah. Ini dapat dilihat apabila Cikgu A bertanya soalan kepada muridnya supaya mereka mengaplikasikan idea yang dipelajari. Cikgu A mengulangi soalan supaya muridnya dapat mengenalpasti apakah itu garis pada satah (Rajah 1):

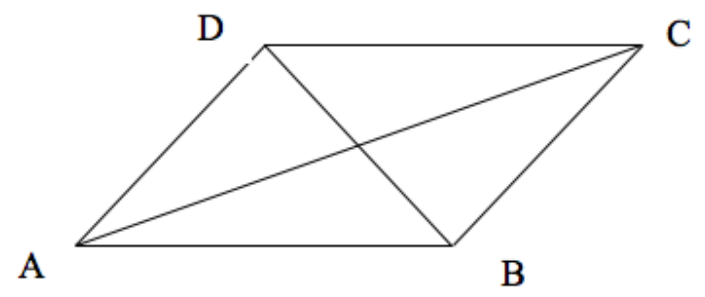

Rajah 1

"Contoh pertama bagi garis pada satah, yang pertama, garis AB" 
Cikgu A sambil menulis di papan tulis dan sambil menamakan contoh garis pada satah. "Okey, Andy, bagi satu lagi." Pelajar yang duduk di baris terakhir sebelah kiri memberikan respons BC. Cikgu A sambil menyebut "BC" sambil menulis di atas papan tulis. Beberapa orang murid lelaki cuba memberikan respons. Antaranya, seorang yang memberikan respons dengan suara yang paling jelas, "CD". Cikgu A mengatakan "Ya, bagus", sambil menulis respons murid di papan tulis. Selepas itu, Cikgu A tanya lagi " Okey, siapa lagi boleh beri? Jerry." Murid yang bernama Jerry pun memberikan respons "DA". Cikgu A katakan "Bagus" dan terus menulis respons pada papan tulis. Seterusnya dia tanya lagi "Ada lagi tak garis pada satah? Tengok betulbetul. Ya, Winnie, apa? Ya, AC. Okey, ada tak lagi?" Cikgu A menoleh ke sebelah kanan. "Ya, BD". Cikgu A menulis jawapan di papan tulis.

\section{iii. Kemajuan}

Cikgu A cuba menerapkan juga nilai kemajuan dalam pengajaran semasa memberikan latihan kepada muridnya. Tujuan latihan diberikan supaya murid berupaya membuat generalisasi terhadap idea yang dibincang untuk digunakan dalam situasi yang lain. Cikgu A menyalin soalan di papan tulis dan menyuruh muridnya mencuba pada akhir pengajarannya. Namun, nilai ini tidak begitu jelas kerana perkembangan murid tidak dapat dikesan dengan jelas melalui hasil kerja mereka.

\section{b. Pengajaran Cikgu B}

Cikgu B telah menerapkan nilai rasionalisme, objektisme, nilai kawalan, nilai kemajuan, nilai keterbukaan dan nilai misteri dalam pengajarannya tentang kes ambiguous. Daripada pemerhatian, pengajaran Cikgu B lebih mementingkan pemerhatian yang dijalankan oleh murid dan kerja murid. Melalui kerja dan pemerhatian, murid akan berkongsi idea dan memberi renspons kepada soalan Cikgu B. Kemudian, idea yang diberi oleh murid akan dibetulkan dengan penjelasan yang lebih tepat.

\section{i. Rasionalisme}

Pengajaran Cikgu B lebih kepada induktif, di mana Cikgu B memberikan murid peluang untuk memberikan idea untuk menemui pengetahuan baharu. Namun, setiap idea yang diberikan akan dibetulkan dengan penjelasan yang lebih tepat. Kesimpulan yang ringkas diberikan oleh Cikgu B supaya idea- idea murid lebih tersusun. Misalnya, dalam memberikan penjelasan bagi syarat kes ambiguous, Cikgu B menyatakan bahawa mesti terdapat satu sisi yang panjang, sudut tirus dan sisi bertentangan dengannya yang lebih pendek.

\section{ii. Objektisme}

Pengajaran Cikgu B menerapkan nilai objektisme. Ini dapat dilihat apabila Cikgu B menggunakan $L C D$ projector untuk menayangkan gambar di atas skrin putih. Selain itu, power point dan geometer's sketchpad yang digunakan juga bertujuan untuk menjadikan idea muridnya konkrit. Dengan menggunakan geometer's sketchpad, 
Cikgu $\mathrm{B}$ menunjukkan dua segitiga $\mathrm{ABC}$ yang berlainan rupa tetapi ukuran $\mathrm{AB}=8 \mathrm{~cm}$, $\mathrm{AC}=4 \mathrm{~cm}$ dan $\square B=40^{\circ}$ seperti Rajah 2 .

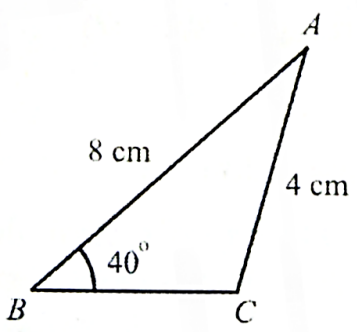

and

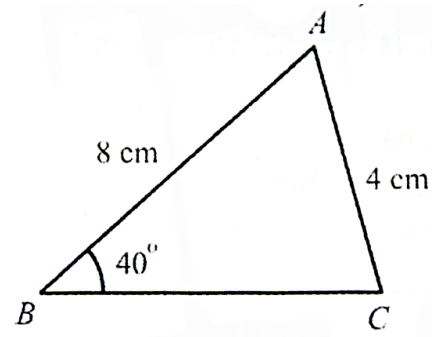

Rajah 2

Kemudian, Cikgu B menunjukkan lagi satu kes bukan ambiguous dengan geometer's sketchpad seperti Rajah 3.

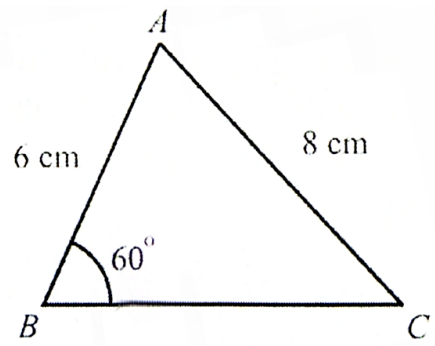

Rajah 3

\section{iii. Kawalan}

Cikgu B menerapkan nilai kawalan semasa aktiviti. Cikgu B membimbing murid mengaplikasikan peraturan baharu yang dimiliki kepada situasi-situasi dalam persekitaran. Cikgu B menunjukkan empat buah segitiga ABC yang tidak sama. Cikgu $\mathrm{B}$ membimbing murid untuk mengenal pasti segitiga $\mathrm{ABC}$ yang mempunyai kes ambiguous secara lisan. Setiap jawapan murid diberi kepastian dan penjelasan yang lebih tepat.

\section{iv. Kemajuan}

Nilai kemajuan diterapkan oleh Cikgu B pada akhir pengajaran. Latihan diberikan dalam bentuk helaian edaran kepada murid. Cikgu B memberikan masa kepada murid untuk mencuba latihan supaya murid dapat membuat generalisasi terhadap kes ambiguous yang dipelajari dalam situasi masalah yang lain. Walau bagaimanapun, nilai ini kurang jelas kerana Cikgu B menghadapi kekangan masa untuk menilai hasil kerja muridnya secara individu.

\section{v. Keterbukaan}

Cikgu B menerapkan nilai keterbukaan dalam pengajaran ini. Cikgu B membenarkan muridnya menyelidik idea matematik, iaitu kes ambiguous. Pada awal pengajaran, 
Cikgu $\mathrm{B}$ menyuruh muridnya melakarkan segitiga $\mathrm{ABC}$ dengan ukuran $\mathrm{AB}=8 \mathrm{~cm}$, $\mathrm{AC}=4 \mathrm{~cm}$ dan $\square B=40^{\circ}$. Dalam aktiviti ini, murid dapati bahawa terdapat dua kemungkinan bagi segitiga $\mathrm{ABC}$. Kes ketidakpastian ini ialah kes ambiguous yang dibincang dalam pengajaran.

\section{vi. Misteri}

Nilai misteri adalah berkait dengan kesukaran memberi makna atau memahami konsep matematik yang dipelajari. Nilai ini diterapkan semasa penerangan kes ambiguous. Cikgu B memberikan makna ambiguous berdasarkan definisi dalam Webster's New World Dictionary:

1) having two or more possible meanings

2) not clear, indefinite, uncertain, vague

Kemudian, Cikgu B menjelaskan ambiguous dengan menggunakan bahasa Melayu, iaitu ketidakpastian. Dua bahasa telah digunakan oleh Cikgu B untuk menjelaskan konsep ambiguous supaya muridnya lebih memahami konsep yang sukar tersebut.

\section{c. Pengajaran Cikgu $C$}

Pengajaran Cikgu C merupakan satu ulang kaji kepada murid sebelum ujian. Pengajaran ini merangkumi sub-topik seperti nombor, pola nombor, persamaan linear dan poligon. Pengajaran Cikgu C melibatkan penerapan nilai nilai objektisme dan nilai kawalan secara tidak langsung.

\section{i. Objektisme}

Cikgu C menerapkan nilai objektisme semasa menyatakan pentagon. Cikgu C melakarkan pentagon dan menekankan bahawan pentagon ialah suatu poligon yang mempunyai 5 sisi. Lakaran ini memberikan gambaran yang konkrit supaya murid dapat membina idea berdasarkan lakaran yang diperhatikan.

\section{ii. Kawalan}

Cikgu C menerapkan nilai kawalan dengan membimbing murid mengaplikasi idea kepada situasi yang lain. Semasa menjelaskan "pembolehubah", Cikgu C menekankan huruf digunakan untuk mewakili pembolehubah. Kemudian, Cikgu $\mathrm{C}$ membimbing murid mengenalpasti persamaan yang terdiri daripada satu pembolehubah.

Kesimpulannya, melalui analisis dokumen dan temu bual, bolehlah disimpulkan bahawa penerapan nilai matematik antara tiga orang guru matematik adalah secara tersirat. Dapatan ini memperlihatkan guru berperanan menerangkan konsep pada awal pengajaran, di samping contoh sebelum akhirnya meminta pelajar menyelesaikan masalah. Justeru, dapatan ini setara dengan dapatan pakar tempatan yang menyatakan bahawa pengajaran matematik didapati lebih berpusatkan guru di mana guru akan mencuba memastikan pelajarnya mendengar segala yang diajar dan diarahkan oleh guru (Mohd Uzi, 2012). Pengajaran sebegini dianggap oleh guru lebih berkesan dan mudah difahami pelajar. 
Dalam konteks individu, nilai yang cenderung diterapkan oleh Cikgu A adalah nilai objektisme, nilai kawalan dan nilai kemajuan manakala Cikgu B pula menerapkan nilai objektisme dan kawalan. Selain itu, Cikgu C pula menerapkan nilai rasionalisme, objektisme, kawalan, kemajuan dan keterbukaan dalam pengajarannya. Dapatan ini memperlihatkan bahawa Cikgu A dan Cikgu B mengajar matematik secara deduktif dan lebih kepada memberikan penerangan dan mengharapkan murid dapat mempelajari konsep daripada penerangan. Namun, dalam pengajaran Cikgu $\mathrm{C}$ yang melibatkan subjek Matematik Tambahan, dia lebih mengharapkan pelajar mempelajari matematik secara yang munasabah melalui proses penghujahan oleh pelajar sendiri. Walau bagaimanapun, dapatan ini selari dengan dapatan kajian lepas di mana ketiga - tiga sampel kajian berpendapat bahawa kekangan masa dalam pengajaran telah menghalang guru untuk melaksanakan segala yang dirancang mengikut jadual (Mohd Uzi, 2012).

\section{Kefahaman Nilai}

Temu bual yang dijalankan oleh pengkaji dengan tiga sampel kajian dirakamkan. Rakaman audio tersebut ditranskripsikan dan dianalisis untuk melihat kefahaman ketigatiga sampel kajian terhadap nilai matematik. Secara umumnya, Cikgu A, Cikgu B dan Cikgu $\mathrm{C}$ berpendapat bahawa matematik mempunyai nilai tersendiri. Namun, mereka menyamakan nilai matematik dengan nilai pendidikan umum seperti berani mencuba dan bekerjasama. Nilai matematik seperti rasionalisme, objektisme dan kemajuan diketahui kepentingannya bagi menjamin pengajaran dan pembelajaran yang berkesan.

\section{a. Kefahaman Nilai Matematik Cikgu A}

Cikgu A menyamakan nilai matematik dengan nilai pendidikan umum seperti nilai-nilai murni dalam pengetahuan moral. Cikgu A menyatakan bahawa nilai ialah amalan yang baik dan dapat menjadikan manusia berakhlak mulia. Bagi Cikgu A, setiap kelas perlu menerapkan nilai murni seperti berani mencuba, sabar dan saling menolong. Selain itu, Cikgu A berpendapat bahawa matematik mempunyai nilai yang mengajar kita sistematik dan tidak mudah putus asa. Nilai ini boleh didapati jika seseorang rajin membuat matematik.

Cikgu A melihat pengajaran matematik merupakan subjek kira-mengira yang melibatkan banyak operasi. Cikgu A juga berpandukan kepada objektif pengajaran dalam pengajaran matematik. Cikgu A tidak menyatakan bahawa nilai matematik sebagai suatu elemen yang penting untuk disampaikan dalam pengajaran matematik.

\section{b. Kefahaman Nilai Matematik Cikgu B}

Cikgu B melihat nilai matematik sebagai nilai murni seperti toleransi, tolong-menolong dan berani mencuba. Cikgu B menyatakan bahawa nilai matematik boleh didapati apabila mengajar dan belajar matematik. Walau bagaimanapun, Cikgu B berpendapat bahawa latihan amat penting bagi memastikan kefahaman murid dalam kelas. Hal ini menunjukkan bahawa Cikgu B faham tentang nilai kemajuan secara tidak langsung. 
Pengajaran matematik melibatkan penyelesaian masalah yang melibatkan operasi tambah, tolak, darab dan bahagi. Pada pendapat Cikgu B, pengajaran matematik juga melibatkan konsep matematik yang lebih sukar kerana subjek yang diajarnya ialah matematik tambahan. Penerapan nilai tidak dinyatakan sebagai satu perkara yang perlu diterapkan dalam pengajaran matematik.

\section{c. Kefahaman Nilai Matematik Cikgu C}

Cikgu $\mathrm{C}$ bersetuju bahawa matematik mempunyai nilainya tersendiri. Cikgu C berpendapat bahawa nilai sama dengan harga, makna, isi, semangat dan konsep. Pandangan Cikgu C terhadap nilai matematik ialah nilai yang diaplikasikan dalam kehidupan seharian melalui pembelajaran matematik. Kefahaman nilai matematik Cikgu C lebih kepada nilai pendidikan umum seperti yang dinyatakannya semasa temu bual, iaitu berani mencuba dan sistematik.

Menurut Cikgu C, latihan yang banyak dan mencabar amat penting untuk murid supaya mereka dapat menguasai sesuatu konsep dengan baik. Hal ini menunjukkan Cikgu $\mathrm{C}$ faham tentang kepentingan nilai kemajuan secara tidak langsung walaupun tidak mengenali definisi nilai tersebut dengan tepat.Cikgu $\mathrm{C}$ melihat pengajaran matematik adalah pengajaran tentang kefahaman konsep yang melibatkan nombor dan tanda operasi untuk menyelesaikan sesuatu masalah. Cikgu C cuba mengajar konsep yang melibatkan nombor dan tanda operasi untuk kegunaan kehidupan seharian dalam pengajarannya.

Kesimpulannya, kefahaman sampel kajian tentang nilai adalah menjurus kepada nilai murni. Antara nilai yang diberikan oleh guru dalam temu bual adalah seperti nilai berani mencuba, nilai kerjasama dan nilai bertanggungjawab. Dapatan ini selari dengan dapatan kajian terdahulu yang dijalankan oleh Mohd Uzi (2010) dan Bishop, FitzSimons, Seah dan Clarkson (1999). Kefahaman tentang nilai sebagai nilai murni ini diperkukuhkan lagi melalui penekanan oleh guru tentang keperluan melaksanakan penerapan nilai murni dalam pengajaran kelas dan catatan dalam rancangan pengajaran harian.

\section{KESIMPULAN}

Secara keseluruhannya, dapatan kajian ini tidak boleh digeneralisasikan. Namun dapatan kajian ini bolehlah dijadikan panduan oleh pensyarah, guru dan merekamereka yang terlibat dengan pendidikan matematik demi mempertingkatkan kualiti pengajaran melalui penekanan kepada pengajaran nilai. Perkara yang jelas dapat disimpulkan di sini adalah tentang kefahaman guru yang dikaji tentang penerapan nilai yang lebih menjurus kepada nilai murni, seperti nilai hormat, nilai kerjasama dan nilai bertanggungjawab. Kesemua mereka tidak menyedari bahawa terdapat nilai selain daripada nilai murni, iaitu nilai melibatkan subjek matematik itu sendiri iaitu nilai matematik dan nilai pendidikan matematik. Bagaimanapun, melalui analisis dokumen dan temu bual, bolehlah disimpulkan bahawa perancangan guru terhadap penerapan nilai pendidikan matematik adalah secara tersirat. 
Dapatan kajian ini boleh disimpulkan bahawa guru-guru menerapkan nilai objektisme dan kawalan secara tersirat dalam pengajaran. Guru matematik mempercayai bahawa objek yang konkrit dapat mengukuhkan konsep matematik yang dipelajari. Selain itu, soalan atau latihan yang sama dan serupa dengan contoh dianggap penting bagi menguji kefahaman murid dalam kelas. Pengajaran matematik tidak dapat dipisahkan daripada latihan matematik.

\section{RUJUKAN}

Mohd Uzi Dollah. (2007). Penerapan nilai dalam pengajaran guru matematik sekolah menengah: satu kajian kes. Tesis yang tidak diterbitkan. Universiti Sains Malaysia, Pulau Pinang, Malaysia.

Mohd Uzi Dollah. (2012). Cabaran Penerapan Nilai Matematik Dalam Pengajaran Matematik Sekolah Menengah. Jurnal Pendidikan Sains dan Matematik Malaysia. $38-50$.

Mohd Uzi Dollah \& Lim Chap Sam. (2009). Penerapan nilai pendidikan matematik dalam pengajaran matematik di sekolah menengah. Journal Sains dan Matematik, $1(2), 29-40$.

Wan Zah Wan Ali, Sharifah Kartini Said Husain, Habsah Ismail, Ramlah Hamzah, Mat Rofa Ismail, Mohd. Majid Konting \& Rohani Ahmad Tarmizi (2005). Kefahaman guru tentang nilai matematik. Jurnal Teknologi Universiti Teknologi Malaysia, 43(E) Dis. 2005: 45-62.

Noor Shah Saad \& Sazelli Ab. Ghani. (2008). Teaching mathematics in secondary schools:Theories and practices. Tanjung Malim, Perak: Penerbit Universiti Pendidikan Sultan Idris.

Bishop, A. J, FitzSimons, G., Seah, W. T., \& Clarkson, P. (1999). Values in mathematics education: Making values teaching explicit in the mathematics classroom. Australia: Values And Mathematics Project (VAMP).

Chien Chin \& Fou-Lai Lin (2001). Value-loaded activities in mathematics classroom. In M. v. d. Heuvel-Panhuisen (Ed.), Proceedings of the 25th conference of the International Group for the Psychology of Mathematics Education, 2. Utrecht. The Netherlands: Freudenthal Institute. Halaman 249-256.

Bishop, A. J. (2000). Overcoming obstacles to the democratisation of mathematics education. Regular lecture presented at the Ninth International Congress on Mathematics Education, Makuhari, Japan.

Dede, Y. (2006). Mathematics educational values of college students' towards function concept. Eurasia Journal of Mathematics, Science and Technology Education, 2 (1), 82-102. Retrieved September 1, 2006, from http://www.ejmste.eom/012006/ d6.pdf

Fang-Chi Lin, Chih-Yeuan Wang, Chien Chin \& Gi-Yuan Chang (2006). Why Students Teachers Or Do Not Teach The Professe Values? Proceedings 30th Conference of the International Group for the Psychology of Mathematics Education, Vol. 4, pp. 81-88. Taiwan: Department of Mathematics, National Taiwan Normal University General Education Centre, Lan Yang Institute of Technology. 